DOI: https://doi.org/10.15407/preislamic2021.02.099

UDC 94(355)

\title{
ARACHOSIA ACCORDING TO OLD PERSIAN ROYAL INSCRIPTIONS
}

\author{
Yu. S. Kukharchyk \\ PhD Student \\ Belarusian State University \\ 6, Krasnoarmeyskaya Str., Minsk, 220030, Belarus \\ kukharchyksch44@gmail.com
}

The paper considers the position of Arachosia in the governance system of the territories captured by the Old Persian royal, based on the Old Persian royal inscriptions. The Old Persian royal inscriptions are a corpus of written sources created in the $4^{\text {th }}-6^{\text {th }}$ centuries BC. They contain the traditional list of dahyu, including a list of territories subject to the Old Persians. Harahuvatiš (Arachosia) is mentioned among of them. It is mentioned in various inscriptions of the Old Persian royal, such as DB, DPE, DNa, DSe, DSm, XPh, DSf. Harahuvatiš (Arachosia) is a vast territory in the basin of the rivers Argentab, Argostan and Ghazni, north of Gedrosia, which was inhabited by Iranian tribes. The Old Persian form of the name of this territory is the equivalent of sank. Sárasvati-, literally means "rich in waters", and is named so in accordance with the main river of the region. According to the geographical list of Videodata, Arachosia mentioned in the list of best countries created by Ahuramazda, thus its population probably, for the most part, adheres to the teachings of Zoroaster and perform the same rituals which are set out in the Avesta. The Behistun inscription mentions Arachosia in connection with the uprisings that swept the empire in the early years of Darius' reign. However, it was not a separate center of the uprising and its population supported the uprising Vahyazdata, as according to the Behistun inscription, the leader of the uprising was not named and the construction "the man who was the head of the army, which Vahyazdata sent against Vivana" was used (DB III.70-71). As the inscriptions of the Achaemenid kings are often accompanied by relief figures, we can determine some of the ethnic characteristics of the inhabitants of Arahosia. tion

Keywords: Arachosia, Ancient Persian royal inscriptions, administration, Behistun inscrip-

\section{Ю. С. Кухарчыюк}

\section{АРАХОСІЯ ПА ДАДЗЕННЫМ СТАРАЖЫТНАПЕРСІДСКІХ ЦАРСКІХ НАДПІСА}

Старажытнаперсідскія царскія надпісы - гэта комплекс пісьмовых крыніц, складзеныя ад імя цароў з дынастыі Ахеменідаў, якія кіравалі Персідскай імперыяй у перыяд паміж VI-IV стст. да н. э. Як правіла, старажытнаперсідскія надпісы складаліся на трох мовах: старажытнаперсідскай, эламскай і акадскай. Пераклады надпісаў на іншыя мовы не з'яўляюцца ідэнтычнымі, паколькі ў іх ёсць адрозненні як структурныя, граматычныя, так і сэнсавыя [Tolman 1908, 175; Дандамаев 1963, 90; Абаев 1971, 271]. Старажытнаперсідская мова разам з мовай Авесты з'яўляюцца найстаражытным пластам іранскіх моў індаіранскай групы індаеўрапейскай моўнай сям'i. Аднак да гэтага часу пытанне аб паходжанні і часе ўвядзення старажытнаперсідскай пісьменнасці канчаткова не вырашана.

Традыцыйна асноўнымі крыніцамі па гісторыі дзяржавы Ахеменідаў і яе частак з'яўляюцца працы антычных аўтараў. Аднак галоўнай крыніцай па гісторыі гэтага 
рэгіёну павінны выступаць тэксты старажытнаперсідскіх царскіх надпісаў. Паколькі яны дазваляюць правесці рэканструкцыю гістарычных падзей ва ўспрыманні непасрэдна персамі. Мэтазгоднасць такога падыходу была абгрунтавана ўжо ў 80-х гг. XX ст., калі сярод даследчыкаў паступова фармулюецца ідэя аб тым, што пры даследаванні розных перыядаў старажытнай гісторыі варта разлічваць на крыніцы, якія бліжэй да падзей [Паркер 1998, 93]. Усе старажытнаперсідскія царскія надпісы былі знойдзены ў розных частках імперыі Ахеменідаў. Найбольшая колькасць надпісаў вядома з Персеполя і яго ваколіц, якія былі выяўлены падчас экспедыцый Чыкагскага ўніверсітэта. Найбуйнейшымі і самымі інфарматыўнымі царскімі надпісамі 3'яўляюцца: Бехістунскі надпіс, два надпісы з Накш-і Рустама Дарыя Вялікага, будаўнічы надпіс і “Антыдэваўскі надпіс” Ксеркса.

Старажытнаперсідскія царскія надпісы фіксуюць інфармацыю пра найбольш важныя справы персідскіх цароў, ствараючы іх станоўчы і гераічны вобраз. Пры гэтым яны адлюстроўваюць афіцыйную пазіцыю дзяржавы, апускаючы ўсе падзеі, нявыгадныя для фарміравання патрэбнага вобразу цара [Медведская 2010, 179]. Вядома, пад час працы з такімі крыніцамі варта ўлічваць іх суб'ектывізм.

Ўсе старажытнаперсідскія надпісы створаны па агульнай структуры і маюць пэўную схему. Як правіла, яны складаюцца з некалькіх элементаў:

- ўводзіны, дзе цар, ад імя якога складзены надпіс, прыводзіць сваю генеалогію;

- упамінанне боскай санкцыі на ўсе дзеянні цара, напрыклад, vašnā : Auramazdāha1 "па волі Ахурамазды”; xšāyatiya : aita : tya : kartam : ava : visam : vašnā : Auramazdāhā : akunavam : Auramazdā(ma)iy : upastām : abara : yātā : kartam : akunavam : mām : Auramazdā : pātuv : hacā : gastā : utāmaiy : vïam : utā : imām : dahyāum : aita : adam : Auramazdām : jadiyāmiy : aitamaiy : Auramazdā : dadātuv - "Гэта, тое, што зроблена. (Я) усё гэта зрабіў па волі Ахурамазды. Ахурамазда мне дапамог, калі зробленае (я) зрабіў. Няхай абароніць мяне Ахурамазда ад зла і мой род, і гэтую краіну! Пра гэта я малю Ахурамазду. Ахурамазда дай мне гэта!” (DNa 48-55); adam : Auramazdām : ayadaiy : Auramazdāmaiy : upastām : abara : tyamaiy : framātam : cartanaiy : ava : ucāramaiy : akunauš : tya : adam : akunavam : visam - "(Ён) мяне царом зрабіў усёй зямлі. Я ўшаноўваў Ахурамазду. Ахурамазда мне дапамог, тое, што мне было загадана рабіць, то лёгка (я) зрабіў. Я зрабіў усе па волі Ахурамазды" (DSf 18-21);

- спіс падуладных тэрыторый;

- асноўная частка, дзе змяшчаецца апісанне пэўнай падзеі (напрыклад, гістарычныя падзеі, як у Бехістунскім надпісы, інфармацыя аб будаўніцтве палаца ў Персеполе, ідэалагічныя асновы дзяржавы, пэўныя рэлігійныя аспекты і г. д.);

- заключэнне. Там змяшчаюцца стандартныя ахоўныя формулы, заклікі да Ахурамазды абараніць сям’ю і справы аўтара. Таксама сустракаюцца і засцярогі ў адрас разбуральнікаў або парушальнікаў, напрыклад, yadiy : imām : dipim : imaivā :

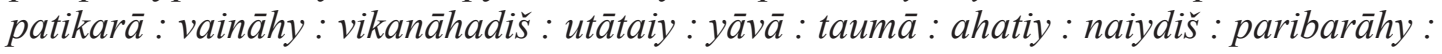

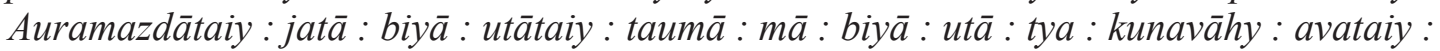
Auramazdā : nikatuv - "Калі гэты надпіс і гэтыя выявы ты ўбачыш (i) ты іх разбурыш, не будзеш ахоўваць, хай Ахурамазда ўдарыць цябе і знішчыць твой род, і разбурыць тое, што ты робіш!” (DB IV 77-80); mām : Auramazdā : pātuv : utāmaiy :

${ }^{1}$ Тут і далей транскрыпцыя старажытнаперсідскага тэксту прыводзіцца па выданні: [Kent 1950], з дапаўненнямі: [Schmitt 1991]. 
Арахосія па дадзенным старажытнаперсідскіх царскіх надпісаў

viӨam - "Няхай Ахурамазда мяне бароніць, мяне і мой род!” (DPh 9-10); martiyā :

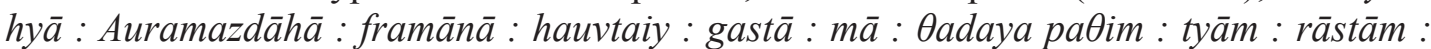
$m \bar{a}:$ avarada : mā : stabava - "О, чалавек, для якога загад Ахурамазды не падаецца злым, ты не пакідай гэты шлях правільны! Не паўставай!” (DNa 56-60); mām : Auramazdā : pātuv : utamaiy : xšaçam : utāa : tya : manāa : kartam : utāa : tyamaiy : piça : kartam : avašciy : Auramazdā : pātuv - "Хай абароніць мяне Ахурамазда і маё царства і тое, што мной зроблена і тое, што маім бацькам зроблена, хай таксама абароніць Ахурамазда" (ХРа 18-20).

У старажытнаперсідскіх надпісах Harahuvatiš - гэта адна 3 dahyu, якія пералічваюцца сярод падпарадкаваных персамі тэрыторый. Пры гэтым яна не толькі адна 3 dahyu, але і асобная адміністрацыйна-палітычная акруга, у грэчаскай перадачы вядомая як сатрапія. Бехістунскі надпіс згадвае, што падчас паўстання Vahyazdāta, сатрапам Aрахосіi быy̆ перс Vivāna (nāma Pārsa manā badaka Harauvatiyā x̌̌a sapāvā (DB III.56)).

Паўстанні 522-521 гг. да н. э. прадэманстравалі нетрываласць Персідскай імперыі. Таму Дарый праводзіць шэраг рэформ, з мэтай яе ўмацавання, каб стварыць ўстойлівую сістэму дзяржаўнага кіравання. Пераўтварэнні закранулі грашовую сістэму, адміністрацыйны лад і сістэму падаткаабкладання. Так, дзяржава была падзелена на ваенна-падатныя акругі - сатрапіi, якія ўзначальваў “х̌̌ asapāvan” сатрап. Аднак варта заўважыць, што старажытнаперсідскі аналаг паняцця сатрапія не засведчаны. Значэнне старажытнаперсідскага хšaçapāvān не выклікае сумніву, яно ўтворана шляхам складання двух асноў назоўніка жаночага роду хšаца “вобласць" [Bartholomae 1904, 546], “царская ўлада", “царства” [Kent 1950, 181] і назоўніка, утворанага ад дзеяслова $p \bar{a}(y)$ “абараняць, ахоўваць, адбіваць” [Bartholomae 1904, 885-886], x̌̌a $a$ + pā + суфікс -van-, гэта значыць “абаронца царства”.

У эламскім варыянце старажытнаперсідскіх надпісаў для Арахосіі выкарыстоўваецца назва har-ra-u-ma-ti-iš, а ў аккадскім - (mâtu) a-ru-ha-at-ti [King 1907, XLVIII]. Таксама існуе і арамейская форма назвы hrhwty [Bowman, 1970, 192b]. Эламскі і акадскі варыянты выкарыстоўваюць тое ж імя, што і старажытнаперсідскія тэксты, што з'яўляецца этымалагічным эквівалентам ведычнага Sárasvatī-, паняцця якое выкарыстоўваецца для назвы ракі, і азначае “багатая водамі/азёрамі”, ад кораня sar “цячы” [Kent 1950, 213].

Такім чынам, Арахосія названа адпаведна яе галоўнай рацэ, сучаснай Аршан-

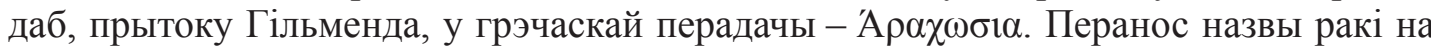
тэрыторыю, дзе яна працякае ці горад, які знаходзіцца на яе берагах, - звычайная практыка. Гэты ж рэгіён згадваецца ў Відэвдаце (1.12) пад мясцовай дыялектнай формай Haraxvaitz̄-. У адпаведнасці з геаграфічным спісам Відэвдата гэта тэрыторыя краіны, узгаданай дзесятай сярод зямель створаных Ахурамаздай. Такім чынам, дадзеная тэрыторыя была заселеная плямёнамі, верагодна, якія ў большасці сваёй, прытрымліваліся вучэння Заратуштры і выконвалі рытуалы, якія прапісаны ў Авесце.

У старажытнаперсідскіх царскіх надпісах тэрмін Harahuvatiš засведчаны ўпершыню ў Бехістунскім надпісу Дарыя I пад час пералічэння краін, заваяваных Ахеменідамі (DB I.9-17). У тэкстах ён ўзгадваецца 11 разоў (гл. табліца 1).

У ахеменідскіх надпісах ужыванне паняцця Harahuvatiš засведчана ў некалькіх выпадках: 
Ю. С. Кухарчык

1. для абазначэння тэрыторыі (dahyu) або сатрапіi: DB I. 17, DPe 17, DNa 2, DSm 10, XPh 20, DB III.55, DSf 44f, DB III.56; III.72; III.76

2. для абазначэння народа, А?P 10.

Табліца 1. Ужыванне Harahuvati у старажытнаперсідскіх царскіх надпісах

\begin{tabular}{|l|l|}
\hline Harauvatis & DB I.17, DPe 17 DNa 2 DSm 10 XPh 20 \\
\hline Harauvatim & DB III.55 \\
\hline Harauvatiya & DSf $44 \mathrm{f}$ \\
\hline Harauvatiy $\bar{a}$ & DB III.56 72 76 \\
\hline Harahuvatiya- & A?P 10 \\
\hline
\end{tabular}

Можна лічыць, што ў Бехістунскім надпісы ўзгадваюцца межы, якія сфарміраваліся ўжо пры Кіры, і Арахосія ўвайшла ў склад дзяржавы Ахеменідаў менавіта пад час кіравання Кіра. Такую выснову можна зрабіць 3 таго факту, што ў 550 г. да н. э. персідскі цар Кір заваёўвае Мідыю, а ў 547 г. да н. э. - Лідыю. Пасля падпарадкавання Лідыі “на шляху Кіра ляжалі Вавілон, бактрыйскі народ, сакі і егіпцяне? (Herod., Hist., I, 153). У 530 г. да н. э. Кір загінуў падчас ваеннага паходу на сярэднеазіяцкіх качэўнікаў. Пасля смерці Кіра "царом цароў” становіцца Камбіз, і яго знешнепалітычная дзейнасць накіроўваецца на захад. Такім чынам, усходняя мяжа не змянялася. Аднак дакладна вызначыць час уваходжання гэтых тэрыторый у склад дзяржавы цяжка і матэрыял старажытнаперсідскіх надпісаў не дазваляе вызначыць храналогію падпарадкавання ўсходніх абласцей, таму яна вызначаецца на аснове паведамленняў Герадота і Ктесія.

Існуе два пункты гледжання па гэтаму пытанню:

1. Усходнія землі, Арахосія ў тым ліку, былі заваяваны ў перыяд паміж падпарадкаваннем Мідыі ў 547 г. да н. э. і ўзяццем Вавілона ў 539 г. да н. э.

2. Кір здзейсніў паход на ўсходнія вобласці пасля 539 г. да н. э.

На сучасным этапе развіцця ведаў абедзве версі, адносна часу ўключэння ўсходніх тэрыторый у склад Персідскай імперы, могуць суіснаваць.

Такім чынам, Harauvatiš хутчэй за ўсё ўвайшла ў склад Персідскай дзяржавы падчас кіравання Кіра.

Часцей за ўсё Harahuvatiš ужжываецца пры пералічэнні заваяваных персамі тэрыторый DB I.14-17, DPe 10-18, DNa 22-30, DSe 21-30, DSm 7-11, XPh 19-28. У сваёй аснове яны ідэнтычныя, але маюць нязначныя разыходжанні, якія можна растлумачыць тэрытарыяльнымі і колькаснымі зменамі сярод краін, што ўваходзілі ў склад імперыі Ахеменідаў (гл. Табліца 2). Абсалютная большасць надпісаў, дзе захаваліся спісы dahyu, складзены ад імя Дарыя I.

Табліца 2. Надпісы Дарыя I і Ксеркса, якія змяшчаюць спісы dahyu

\begin{tabular}{|c|c|}
\hline $\begin{array}{c}\text { Надпіс } \\
\text { (месца ў тэксце) }\end{array}$ & $\begin{array}{c}\text { Пералік усходніх тэрыторый Персідскай імперыі, сярод якіх сустракаецца } \\
\text { паняцце Harauvatiš }\end{array}$ \\
\hline DB (16-17) & $\begin{array}{l}\text { Haraiva : Uvārazmīy : Bāxtriš : Suguda : Saka : @ataguš : Harauvatiš } \\
\text { Maka }\end{array}$ \\
\hline $\begin{array}{c}\mathrm{DPe} \\
(16-18)\end{array}$ & $\begin{array}{l}\text { Haraiva : Bāxtriš : Suguda : Uvārazmīy : Qataguš : Ha } \\
\text { Gadāra : Sakā : Maka }\end{array}$ \\
\hline
\end{tabular}


Арахосія па дадзенным старажытнаперсідскіх царскіх надпісаў

\begin{tabular}{|c|c|}
\hline $\begin{array}{c}\mathrm{DNa} \\
(23-26)\end{array}$ & $\begin{array}{l}\text { Bāxtriš : Suguda : Uvārazmiš : Zraka : Harauvatiš : @ataguš : Gadāra : } \\
\text { Hiduš }\end{array}$ \\
\hline $\begin{array}{c}\mathrm{DSe} \\
(21-25)\end{array}$ & $\begin{array}{l}\text { Haraiva : Bāxtriš : Suguda : Uvārazmiš : Zraka : Harauvatiš : @ataguš : } \\
\text { Maciyā : Gadāra : Hiduš }\end{array}$ \\
\hline $\begin{array}{l}\mathrm{DSm} \\
(8-9 \ldots)\end{array}$ & $\begin{array}{l}\text { Zraka : Haraiva : Uvārazmī̌s : Bāxtrišs : Suguda : Gadāra : @ataguš : } \\
\text { Harauvatiš : Hiduš }\end{array}$ \\
\hline $\begin{array}{c}\mathrm{XPh} \\
(20-21)\end{array}$ & Māda : Ujja : Haranvatiš : Armina: \\
\hline
\end{tabular}

Практычна ўсе краіны, якія згадваюцца ў надпісах персідскіх цароў, згрупаваныя пэўным чынам: краіны, якія суседнічаюць паміж сабой, згадваюцца разам. Ва ўсіх надпісах Harauvatiš згадваецца разам з @ataguš (Саттагідзія), тэрыторыя, 3 якой Арахосія дакладна мела агульную мяжу, і побач з Hiduš (Індыяй) (DPe, DSm) або Zraka (Дрангіаной) (DNa, DSe). У Бехістунскім надпісы замест Індыі, побач з Apaхосіяй згадваецца Maka (Мака).

Выключэннем з'яўляецца “Антыдэваўскі надпіс", дзе Harauvatiš па незразумелым прычынам размешчана сярод заходніх земляў.

Варта сказаць, што калі абапірацца выключна на надпісы Ахеменідаў, немагчыма дакладна лакалізаваць Арахосію. Аднак можна зрабіць выснову, што яна размяшчалася на ўсходнім памежжы, побач з Індыяй, Гандарай і ўсходнімі сатрапіямі. Згодна “Будаўнічаму надпісу” яна ўзгадваецца разам з Індыяй як крыніца слановай косці, якую прывозілі для будаўніцтва палаца Дарыя, piruš : hya : idā : karta : haca : Küšs $:$ utā : hacā : Hidauv : utā : hacā : harauvatiyā : abariya "слановая костка, якая тут выкарыстана, з Эфіопіі і з Індыі, і з Арахосіі была прынесена” (DSf 42-43).

У старажытнаперсідскіх царскіх надпісах згадваецца сатрапія, 3 цэнтрам у Арахосіi. Пры гэтым у склад гэтай сатрапіi, хутчэй за ўсё, уваходзіла і Саттагідзія, паколькі ў Бехістунскім надпісу, пасля таго як Дарый задушыў паўстанне ў Саттагідзіі, ён напісаў pasāva : dahyāuš : manā : abava : ima : tya : manā : kartam: Harauvatiya, “...вось што мной зроблена ў Арахосіi” (Bh III.75-76). Такім чынам, персідскія сатрапіі, вельмі часта, уключалі ў сябе некалькі розных народаў і тэрыторый дзяржаў, якія раней былі незалежнымі (аналагічную карціну мы назіраем з Бактрыйскай сатрапіяй і Маргіянай). Паўнамоцтвы персідскіх сатрапаў былі досыць шырокія. Найважнейшая функцыя дзяржаўнага апарата, якую павінен быў выконваць сатрап, - збор падаткаў. Згодна 3 новай падатковай сістэмай Дарыя, кожная сатрапія абавязаная была плаціць асноўны гадавы падатак грашыма. Старажытнаперсідскія царскія надпісы паведамляюць, што ўсе падпарадкаваныя народы плацілі даніну ў казну imāa: dahyāva : tyā : adam : adaršiy : hadā : anā : Pārsāa : kārāa : tyā : hacāma : atarsa : manā : bājim: abara (DPe 7-10) [пералік краін], г. зн. “...(вось) гэтыя краіны, якія я трымаў разам з персідскім войскам, якія мяне баяліся, мне даніну падносілі”. Блізкія па зместу пасажы змяшчаюць і іншыя старажытнаперсідскія надпісы: DNa 16-30, DSe 15-21 і інш. Пра тое, што залежныя ад персаў землі павінны былі плаціць даніну, узгадваюць і грэчаскія аўтары. Герадот сцвярджае, што ўсе народы плацілі даніну срэбрам або золатам (Herod., Hist., III, 89). Дарый упершыню на тэррыторыі ўсёй краіны ўстанавіў фіксаваны аб'ём падаткаў. Там жа Герадот узгадвае аб'ёмы падаткаў, якія плацілі уусходнія сатрапіі (Herod., Hist., III, 89-97). 
Акрамя абавязковай даніны (baji-), падпарадкаваныя народы павінны былі падносіць цару падарункі. Рэльефы ападаны ў Персеполе паказваюць народы, якія вядуць для цара розных жывёл і нясуць ўпрыгожванні і посуд. Мяркуецца, што гэтыя сцэны паказваюць дастаўку ў палац падарункаў на Новы год, якія ўносіліся натурай [Дандамаев, Луконин 1980, 188]. Магчыма жыхары Арахосіі намаляваны на ўсходняй лесвіцы ападаны (дэлегацыя № 7) у Персеполе (бяззбройны кіраўнік дэлегацыі і тры асобы побач з ім, якія аднолькава апрануты). Выявы дэлегатаў моцна разбураныя, таму іх ідэнтыфікацыя недакладная і спрэчная [Schmidt 1953 pl. 37,b]. Выявы жыхароў Арахосіі прысутнічаюць і на іншых рэльефах, напрыклад, на магіле Дарыя ў Накш-і Рустаме, аднак ідэнтыфікацыя застаецца спрэчнай, і прадстаўнікоў гэтых этнічных групп, аб'ядналі ў адну группу як жыхароў усходніх тэрыторый [Schmidt 1970, 149].

Старажытнаперсідскія рэльефы дакладна малююць розныя народы, перадаюць асаблівасці не толькі іх адзення, але і вонкавага выгляду. Аднак варта заўважыць, што не ўсе этнічныя групы паддаюцца дакладнай ідэнтыфікацыі. У сваёй аснове ўсе выявы залежных народаў схематычныя і стылізаваныя, і некаторыя асаблівасці вонкавага аблічча не адлюстраваны [Яценко 2011a, 499]. Для ідэнтыфікацыі прадстаўнікоў розных народаў варта абапірацца, у першую чаргу, на падобныя выявы на фасадах грабніц ў Накш-і Рустаме, таму што ў Накш-і Рустамскім надпісу Дарыя паслядоўнасць пералічэння народаў суадносіцца з парадкам іх скульптурных малюнкаў [Schmidt 1953, 117]. Падобнае, а, часам, ідэнтычнае адзенне і ўзбраенне паказваюць на рэльефах прадстаўнікоў груп, якія этнічна роднасныя адзін аднаму i займаюць суседнія геаграфічныя тэрыторыі з аналагічнымі кліматычнымі ўмовамі [Schmidt 1953, 117; Яценко 20116, 111]. Нажаль, шматлікія персепольскія рэльефныя выявы моцна разбураныя і не даюць нам поўнай карціны ўяўленняў аўтараў, якія іх стварылі.

Народы Персідскай імперыі, павінны былі падпарадкоўвацца агульнаперсідскаму закону (data), то бок прытрымлівацца парадку і выконваць пэўныя функцыі, atar : imā : dahyāva : martiya : hya : agriya : āha : avam : ubartam : abaram : hya: arika : āha : avam : ufrastam : aparsam : vašnā : Auramazdāha : imā : dahyāva : tyanā :

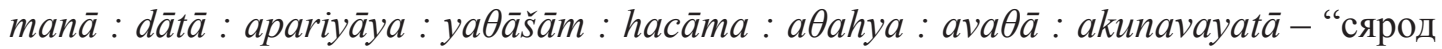
гэтых краін чалавека, хто лаяльным быў, я ўзнагароджваў, хто варожым быў, я караў. Па волі Ахурамазды гэтыя краіны майго закону прытрымліваліся. Як ім было сказана, так было зроблена (імі)” (DB I. 20-24); tyašām : hacāma : aAahya : ava : akunava : dātam : tya : manā : avadiš : adāraiya [пералік стрн] - "тое, што было сказана мною ім, то (імі было) зроблена. Закон мой, (які) трымаў іх" (DNa 16-22). Аналагічныя пасажы змяшчаюць і іншыя старажытнаперсідскія царскія надпісы: DSe 14-21, XPh 14-19 і інш.

Падпарадкаваныя народы павінны былі несці і ваенную павіннасць: удзельнічаць у ваенных кампаніях у агульнаперсідскім войску пад кіраўніцтвам персідскага цара. Акрамя ваеннай павіннасці, у розных частках імперыі існавалі розныя майстэрні, якія павінны пастаўляць сваю прадукцыю для царскага палаца. Так, у Арахосіі былі майстэрні, якія выраблялі посуд для двара персідскага цара, гэтая выснова была зроблена на падставе вывучэння персепольскіх надпісаў на арамейскай мове [Дандамаев, Луконин 1980, 185]. 
Арахосія па дадзенным старажытнаперсідскіх царскіх надпісаў

Для пабудовы палацу Дарыя дастаўлялі матэрыялы з 12 краін імперыі, у тым ліку і з Арахосіі. Адсюль везлі слановую косць. Арахонты былі на службе ў “цара цароў” у якасці дзяржаўных чыноўнікаў. У дакументах з Персеполя можна знайсці інфармацыю пра паездкі па краіне чыноўнікаў і работнікаў з Арахосіі [Дандамаев, Луконин 1980, 281].

Арахосія не была цэнтрам асобнага паўстання ў адрозненні ад некаторых іншых тэррыторый. Паўстанне ў Арахосіі было ініцыявана пасылкай Вах’яздаты свайго прыхільніка. Яго імя ў Бехістунскім надпісу не называецца, і выкарыстоўваецца складаная канструкцыя, кшталту pasāva : hauv : martiya : hya : avahyā : kārahyā : matišta : āha : tyam : Vahyazdāta : frāišaya : abiy Vivānam - "чалавек, які быў начальнікам таго войска, якое Вах'яздата паслаў супраць Віваны” (DB III.7071). Магчыма, гэта тлумачыцца тым, што ў Бехістунскім надпісу называюцца імёны толькі прыхільнікаў Дарыя або імёны паўстанцаў, якія аб'яўлялі сябе царамі, спадкаемцамі трона. А кіраўнік паўстання ў Арахосіі быў толькі прыхільнікам Вах'яздаты, таму яго імя не ўзгадваецца.

У сувязі з развіццём рамёстваў на тэрыторыі ўсходніх сатрапій фарміруецца сістэма гарадскіх паселішчаў, якія з'яўляліся цэнтрамі зямельнай акругі, а некаторыя рэзідэнцыямі мясцовых кіраўнікоў. У персідскіх крыніцах згадваецца тры тыпы паселішчаў: didā, vardana і $\bar{a} v a h a n a$. У дачыненні да населенных пунктаў у Арахосіі двойчы выкарыстоўваецца тэрмін didā (“умацаванае паселішча, крэпасць”, “сцяна” [Bartholomae 1904, 365]).

Гісторыя Арахосіі персідскага перыяду пасля падзей 20-х гг. VI ст. да н. э. невядомая. Некаторыя звесткі можна знайсці ў працах грэчаскіх аўтараў. Так Аррыян, паведамляе, што архонты, пад кіраўніцтвам сатрапа Барэнта ўдзельнічалі ў змове супраць Дарыя III, падтрымаўшы бактрыйскага сатрапа (Arr., Anab., 3.8.4; 21.1). Далей у грэчаскіх тэкстах ёсць толькі ўзгадванні аб прызначэнні розных сатрапаў, (напрыклад, Arr., Anab., 3.28.1, 5. 6.2; Curt., 7.3.5; Diod., 18.3.3 і інш.).

Такім чынам, Арахосія - гэта ўсходняя сатрапія Персідскай імперыі, куды ўваходзіла таксама Саттагідзія, якая была ўключана ў склад дзяржавы Кірам Вялікім. У адпаведнасці з заведзенымі парадкамі, жыхары Арахосіі плацілі як штогадовую грашовую даніну, так і натуральную.

Відавочна, што старажытнаперсідскія царскія надпісы з'яўляюцца унікальнымі і важнымі крыніцамі не толькі па гісторыі старажытнага Ірана, але і па гісторыі яго ўсходніх земляў.

\section{ЛІТАРАТУРА}

Абаев В. И. Из иранской ономастики // История Иранского государства и культуры: К 2500-летию Иранского государства / Ред. Б. Г. Гафуров. Москва, 1971.

Дандамаев М. А. Иран при первых Ахеменидах (VI в. до н. э.). Москва, 1963.

Дандамаев М. А., Луконин В. Г. Культура и экономика Древнего Ирана. Москва, 1980.

Медведская И. Н. Древний Иран накануне империй (IX-VI вв. до н. э.). История Мидийского царства. Санкт-Петербург, 2010.

Паркер $B$. О чем умалчивает Геродот. Заметки о передаче сведений о киммерийцах у греческих авторов помимо Геродота // Вестник древней истории. 1998. № 4. 
Ю. С. Кухарчык

Яиенко С. А. Враги из Средней Азии в искусстве империи Ахеменидов // Вопросы археологии Казахстана / Ред. А. 3. Бейсенов. Алматы, $2011 a$.

Яиенко С. А. Северное Причерноморье и Ахемениды: некоторые аспекты взаимоотношений // Боспорский феномен. Население, языки, контакты. Материалы международной научной конференции, 22-25 ноября 2011 г. Санкт-Петербург, 20116 .

Bowman R. A. Aramaic Ritual Texts from Persepolis. Chicago, 1970.

Bartholomae Chr. Altiranisches Wörterbuch. Strassburg, 1904.

Kent R. G. Old Persian: Grammar, Text, Lexicon. New Haven, 1950.

King $L$. The sculptures and inscription of Darius the Great on the rock of Behistūn in Persia. London, 1907.

Schmidt E. Persepolis I: Structures, Reliefs, Inscriptions. Chicago, 1953.

Schmidt E. Persepolis III: Royal Tombs and Other Monuments. Chicago, 1970.

Schmitt R. The Bisitun Inscriptions of Darius the Great Old Persian Text. London, 1991.

Tolman H. C. A Guide to the Old Persian Inscriptions. Tennessee, 1908.

\section{REFERENCES}

Abayev V. I. (1971), "Iz iranskoy onomastiki", in B. G. Gafurov (ed.), Istoriya Iranskogo gosudarstva i kultury: K 2500-letiyu Iranskogo gosudarstva: sbornik statey, Glavnaya redaktsiya Vostochnoy literatury, Moscow, pp. 262-76. (In Russian).

Dandamayev M. A. (1963), Iran pri pervykh Akhemenidakh (VI v. do n. e.), Izdatel'stvo Vostochnoy literatury RAN, Moscow. (In Russian).

Dandamayev M. A. and Lukonin V. G. (1980), Kul'tura i ekonomika Drevnego Irana, Izdatel'stvo "Nauka", Glavnaya redaktsiya Vostochnoy literatury RAN, Moscow. (In Russian).

Medvedskaya I. N. (2010), Drevniy Iran nakanune imperiy (IX-VI vv. do n. e.). Istoriya Midiyskogo tsarstva, Izdatel'stvo "Peterburgskoye Vostokovedeniye", Saint Petersburg. (In Russian).

Parker V. (1998), "O chem umalchivayet Gerodot. Zametki o peredache svedeniy o kimmeriytsakh u grecheskikh avtorov pomimo Gerodota Azii”, Vestnik drevney istorii, No. 4, pp. 93-102. (In Russian).

Yatsenko S. A. (2011), "Vragi iz Sredney Azii v iskusstve imperii Achemenidov", in A. Z. Beysenov (ed.), Voprosy arkheologii Kazakhstana, Institut arkheologii im. A. Kh. Margulana, Almaty, pp. 495-510. (In Russian).

Yatsenko S. A. (2011), "Severnoye Prichernomor'ye i Akhemenidy: nekotoryye aspekty vzaimootnosheniy", Bosporskiy fenomen. Naseleniye, yazyki, kontakty, Materialy mezhdunarodnoy nauchnoy konferentsii, November 22-25, 2011, Saint Petersburg, pp. 109-13. (In Russian).

Bowman R. A. (1970), Aramaic Ritual Texts from Persepolis, The University of Chicago Press, Chicago (Illinois).

Bartholomae Chr. (1904), Altiranisches Wörterbuch, Verlag von Karl J. Trübner, Strassburg.

Kent R. G. (1950), Old Persian: Grammar, Text, Lexicon, American Oriental Society, New Haven (Connecticut). 
Арахосія па дадзенным старажытнаперсідскіх царскіх надпісаў

King L. The sculptures and inscription of Darius the Great on the rock of Behistūn in Persia, Oxford University Press, Amen Corner, London.

Schmidt E. (1953), Persepolis I: Structures, Reliefs, Inscriptions, The University of Chicago Press, Chicago (Illinois).

Schmidt E. (1970), Persepolis III: Royal Tombs and Other Monuments, The University of Chicago Press, Chicago (Illinois).

Schmitt R. (1991), The Bisitun Inscriptions of Darius the Great Old Persian Text, School of Oriental and African Studies, London.

Tolman H. C. (1908), Ancient Persian Lexicon and the Texts of the Achaemenidan Inscriptions Transliterated and Translated with Special Reference to Their Recent Reexamination, Published by Vanderbilt University, Nahville (Tennessee).

\section{Ю. С. Кухарчық \\ АРАХОСІЯ ПА ДАДЗЕННЫМ СТАРАЖЫТНАПЕРСІДСКІХ ЦАРСКІХ НАДПІСА Ў}

У рабоце разглядаецса становішча Арахосіі ў сістэме кіравання захопленымі персідскімі царамі тэрыторый. Давледванне грунтуецца на старажытнаперсідскія царскіх надпісах. Старажытнаперсідскія царскія надпісы - гэта корпус пісьмовых крыніц, створаных ў IVVI стст. да н. э. У іх змяшчаецца традыцыйны спіс dahyu, які ўключае спіс падуладных персам тэрыторый. Сярод іх згадваецца Harahuvatiš (Арахосія). Яна згадваецца ў розных надпісах персідскіх цароў, такіх як DB, DPe, DNa, DSe, DSm, XPh, DSf. Harahuvatiš (Арахосія) уяўляе сабой вялікую тэрыторыю ў басейне рэк Аргендаба, Аргастана і Газні, на поўнач ад Гедросіі, якая была населена іранскімі плямёнамі. Старажытнаперсідская форма назвы гэтай тэрыторыі з'яўляецца эквівалентам санск. Sárasvatī- і даслоўна азначае "багатая водамі”, i названая так ў адпаведнасці з галоўнай ракой рэгіёну. У адпаведнасці з геаграфічным спісам Відэвдата Арахосія згадваецца ў спісе лепшых краін, створанных Ахурамаздай, то бок яе насельніцтва, верагодна, у большасці сваёй, прытрымліваецца вучэння Заратуштры і выконвае тыя ж рытуалы, якія прапісаны ў Авесце. Бехістунскі надпіс згадвае Арахосію ў сувязі з паўстаннямі, якія ахапілі імперыю ў першыя гады праўлення Дарыя. Аднак яна не з'яўлялася асобным цэнтрам паўстання, а яе насельніцтва падтрымала паўстанне Вах'яздаты, паколькі згодна Бехістунскаму надпісу, кіраўнік паўстання не быў названы, а была выкарыстана канструкцыя “Чалавек, які быў начальнікам таго войска, якое Вах'яздата паслаў супраць Віваны” (DB III.70-71). Паколькі надпісы ахеменідскіх цароў часта суправаджаюць рэльефныя малюнкі, то мы можам вызначыць і некаторыя этнічныя асаблівасці жыхароў Арахосіi.

Ключавыя словы: Арахосія, старажытнаперсідскія царскія надпісы, кіраванне, Бехістунскі надпіс

$$
\text { Ю. С. Кухарчик }
$$

\section{АРАХОСІЯ ЗА ДАНИМИ ДАВНЬОПЕРСЬКИХ \\ ЦАРСЬКИХ НАПИСІВ}

В роботі розглядається положення Арахосії в системі управління захоплених перськими царями територій на базі давньоперських царських написів. Давньоперські царські написи - це корпус письмових джерел, створених у IV-VI ст. до н. е., в яких міститься традиційний звід dahyu, що включає список підвладних персам територій. Серед них згадується Harahuvatiš (Арахосія). Вона згадується в різних написах перських царів, таких як DB, DPE, DNa, DSe, DSm, XPh, DSf. Harahuvatiš (Арахосія) являє собою велику територію в басейні річок Аргентаба, Аргостана та Газні, на північ від Гедросії, яка була населена іранськими племенами. Давньоперською форма назви цієї території є еквівалентом санк. Sárasvatī- і дослівно вона означає “багата водами”, і названа так відповідно до головної 
Ю. С. Кухарчык

річки регіону. Згідно до географічного опису Відевдата Арахосія, згадується в списку кращих країн, створених Ахуромаздою, тобто ії населення, ймовірно, в більшості своїй, дотримується вчення Заратуштри і виконує ті ж ритуали, які прописані в Авесті. Бехістунський напис згадує Арахосію в зв'язку з повстаннями, що охопили імперію в перші роки правління Дарія. Однак вона не була окремим центром повстання, а іiі населення підтримало повстання Вах'єздати, оскільки згідно до Бехістунського напису керівник повстання не названий, а була використана конструкція “людина, яка була начальником тієї армії, яка Вах'єздата послав проти Віва” (DB III.70-71). Оскільки написи ахеменідських царів часто супроводжують рельєфні малюнки, то ми можемо визначити і деякі етнічні особливості жителів Арахосії.

Ключові слова: Арахосія, давньоперські царські написи, Бехістунський напис 